ISSN : 2303-1514 | E-ISSN : 2598-5949

\title{
DEVELOPING MIND MAPPING BASED POCKET BOOK LEARNING MEDIA FOR UNDERSTANDING THE CONCEPT OF INDONESIAN GEOGRAPHIC CONDITIONS MATERIALS AT GRADE V ELEMENTARY SCHOOL
}

\author{
Desi Ayu Pratiwi ${ }^{1}$, Ana Nurhasanah², Zerri Rahman Hakim ${ }^{3}$ \\ ${ }^{1,2,3}$ Universitas Sultan Ageng Tirtayasa, Serang, Indonesia \\ I'desiayupratiwi.smf@gmail.com, ${ }^{2}$ ananur74@untirta.ac.id, ${ }^{3}$ zerrirahmanhakim@gmail.com
}

\section{PENGEMBANGAN MEDIA PEMBELAJARAN BUKU SAKU BERBASIS MIND MAPPING TERHADAP PEMAHAMAN KONSEP MATERI KEADAAN GEOGRAFIS INDONESIA DI KELAS V SD}

\section{ARTICLE HISTORY}

Submitted:

16 oktober 2020

$16^{\text {st }}$ October 2021

Accepted:

02 Januari 2021

$02^{\text {nd }}$ January 2021

Published:

20 Februari 2021

$20^{\text {nd }}$ February 2021

\section{ABSTRACT}

Abstract: This study was a research and development which was based on Borg and Gall model modified by Sugiyono. This model divided the steps of the development process into 6 stages: 1) problem analysis, 2) data collection, 3) product design, 4) validation testing, 5) product revision, and 6) limited testing. This study aimed to produce a product of Mind Mapping-based Pocket Book Learning Media for Understanding the Concept of Indonesian Geographical Materials at grade V. This study also aimed to determine the level of feasibility and understanding of students towards Mind Mapping-based Pocket Book on Indonesian Geographical Conditions. The subjects in this study were 17 fifth grade students of SDN Cimunang Cilik. The analysis technique used in this research was the feasibility analysis technique of expert judgement and students' understanding tests. The results of this study showed that the results of the assessment by media experts obtained an average percentage of $89.2 \%$ with the category "Very Feasible" while the results of the assessment by material experts obtained an average percentage of $91 \%$ with the category "Very Feasible", and the results of the assessment by linguists obtained an average percentage of $82.8 \%$ in the category of "Very feasible". Finally, the results of the test of students' understanding got an average score of 88.2 in "Good" category. The results of this study indicated that Mind Mapping-based Pocket Book learning media could be used to improve students' understanding on the material of Indonesia's geographical conditions.

Keywords: Pocket Book, Mind Mapping, Concept Understanding

\begin{abstract}
Abstrak: Penelitian ini merupakan penelitian dan pengembangan menurut Borg and Gall dimodifikasi oleh Sugiyono. Model penelitian ini membagi langkah proses pengembangan ini menjadi 6 tahap, yaitu 1) analisis masalah, 2) pengumpulan data, 3) desain produk, 4) uji validasi, 5) revisi produk, dan 6) uji coba terbatas. Penelitian ini bertujuan untuk menghasilkan produk pengembangan yang berupa Media Pembelajaran Buku Saku berbasis Mind Mapping terhadap Pemahaman Konsep Materi Geografis Indonesia di Kelas V SD. Penelitian ini juga bertujuan untuk mengetahui tingkat kelayakan dan pemahaman siswa terhadap Buku Saku berbasis Mind Mapping Materi Keadaan Geografis Indonesia. Subjek pada penelitian ini adalah 17 siswa kelas V SDN Cimunang Cilik. Teknik analisis yang digunakan pada penelitian ini menggunakan teknik analisis kelayakan uji ahli dan tes pemahaman siswa. Hasil penelitian menunjukkan hasil penilian oleh ahli media diperoleh rata-rata persentase $89.2 \%$ dengan kategori "Sangat Layak", hasil penilian oleh ahli materi diperoleh rata-rata persentase $91 \%$ dengan kategori "Sangat Layak, hasil penilaian oleh ahli bahasa diperoleh rata-rata persentase $82.8 \%$ dengan kategori "Sangat Layak", dan hasil tes pemahaman siswa memperoleh nilai rata-rata 88.2 dengan kategori "Baik". Hasil penelitian ini menunjukkan bahwa media pembelajaran Buku Saku berbasis Mind Mapping dapat digunakan untuk meningkatkan pemahaman siswa pada materi keadaan geografis Indonesia.
\end{abstract}

Kata Kunci: Buku Saku, Mind Mapping, Pemahaman Konsep 


\section{CITATION}

Pratiwi. A. D., Nurhasanah. A., \& Hakim. R. A. (2021). Developing Mind Mapping-Based Pocket Book Learning Media for Understanding the Concept of Indonesian Geographic Conditions Materials at Grade V Elementary School. Primary: Jurnal Pendidikan Guru Sekolah Dasar, 10 (1), 67 - 78. DOI: http://dx.doi.org/10.33578/jpfkip.v10i1.8068.

\section{PENDAHULUAN}

Aspek pengetahuan, keterampilan dan sikap dapat didapat melalui kegiatan pembelajaran di kelas. Pada sekolah dasar, siswa mendapakan pengetahuannya dari berbagai mata pelajaran yang diikutinya, salah satunya ialah mata pelajaran Ilmu Pengetahuan Sosial (IPS). Tujuan pendidikan IPS salah satunya ialah agar siswa mendapatkan pengetahuan (knowledge) baik pengetahuan mengenai mengenal diri pribadinya maupun mengenai lingkungannya sosial disekitarnya. Sebelum siswa mendapatkan pengetahuan seperti yang dimaksud pada tujuan pembelajaran IPS, siswa harus terlebih dahulu memahami dan mencapai pemahaman mengenai suatu konsep yang dipelajarinya.

Pencapaian tujuan pembelajaran IPS tidak akan terlepas dari kegiatan pembelajaran yang dilakukan guru dan siswa dengan fasilitas pembelajaran yang digunakan guru, sebagai penunjang keberhasilan kegiatan pembelajaran. Proses pembelajaran dapat berjalan dengan optimal dan baik, guru tentu saja harus melibatkakan siswa dalam kegiatan pembelajaran. Siswa dapat berperan aktif apabila guru memberi stimulus agar membangkitkan rasa ingin tahu siswa, sehingga siswa ikut berperan aktif dan dapat berpikir kritis terkait apa yang sedang dipelajari di kelasnya. Namun, para guru belum sepenuhnya melaksanakan kegiatan pembelajaran aktif yang menyertakan siswa terlibat dalam kegiatan pembelajaran. Permasalahan yang banyak terjadi ialah banyaknya guru masih menggunakan metode pembelajaran konvensional seperti ceramah yang menyebabkan siswa cenderung pasif dalam proses pembelajaran, karena siswa hanya duduk diam mendengarkan dan hanya menerima apa yang disampaikan oleh guru.
Bentuk pola belajar yang seperti itu dapat menyebabkan siswa merasa jenuh sehingga siswa menganggap bahwa pembelajaran IPS ialah pembelajaran yang monoton dan kurang veriatif. Apabila siswa merasa jenuh dan tidak tertarik terhadap kegiatan pembelajaran, akan mengakibatkan siswa akan merasa terpaksa dalam mengikuti kegiatan pembelajaran dan siswa akan kesulitan menerima meteri atau informasi yang diberikan guru (Shoimin, 2014:18). Jika siswa kesulitan dalam belajar tentunya konsep yang dipelajarinya tidak akan tercapai. Maka dari itu seorang guru perlu merencanakan kegiatan pembelajaran yang dapat membangkitkan motivasi dan minat belajar siswa, yakni salah satunya dengan menggunakan media pembelajaran.

Penggunaan media pembelajaran sebagai tempat penyalur pesan dan informasi belajar dalam proses pembelajaran dapat membangkitkan keinginan dan minat serta membangkitkan motivasi dan rangsangan belajar. Penggunaan media pembelajaran pada proses pembelajaran akan sangat membantu keefektifan proses pembelajaran yakni mempermudah guru dalam menyampaikan materi dan isi pembelajaran. Dalam mengunakan media pembelajaran guru harus memperhatikan beberapa hal, karena tidak semua media pembelajaran cocok digunakan pada setiap materi ajar. Menentukan media pembelajaran yang akan digunakan dalam pembelajaran, tentunya guru harus mempertimbangkan beberapa faktor seperti kompetensi yang ingin dicapai, tujuan pembelajaran, materi, perkembangan maupun karakteristik siswa.

Media pembelajaran sangat berperan penting dalam kegiatan pembelajaran, selain mempermudah guru dalam menyampaikan 
materi ajar, media pembelajaran juga berfungsi untuk menyampaikan bagian-bagian tertentu yang tidak bisa dijelaskan secara verbal atau secara lisan. Sayangnya penggunaan media tidak dimanfaatkan secara maksimal, setiap kegiatan pembelajaran guru hanya mengandalkan dirinya sebagai sumber informasi dan sumber belajar bagi siswa. Selain itu, sumber belajar yang digunakan hanya berupa buku pokok yaitu buku paket dan buku pendamping (LKS). Buku yang terdapat di sekolah kurang menarik perhatian siswa karena bentuknya yang besar dan tidak berwarna sehingga membuat siswa kurang berminat untuk menggunakannya.

Berdasarkan wawancara yang dilakukan peneliti pada tanggal 6 November 2019 dengan Ibu Sarinah, S.Pd selaku guru kelas VA di SDN Cimuncang Cilik, diketahui bahwa dalam kegiatan pembelajaran guru jarang menggunakan media pembelajaran, guru hanya menggunakan media pembelajaran pada materi tertentu apabila dirasa materi tersebut membutuhkan alat perantara atau media dalam penyampaiannya dan media tersebut yang sudah ada sekolah seperti globe. Setiap harinya guru hanya menggunakan sumber belajar yaitu buku siswa sebagai media pembelajaran. Buku tersebut merupakan buku pinjaman dari sekolah untuk siswa. Minimnya buku referensi yang dimiliki oleh siswa sebagai buku pelengkap dalam pembelajaran, menyebabkan siswa kurang memiliki wawasan yang lebih luas. Pada pembelajaran IPS dengan materi yang luas diperlukan suatu cara untuk agar siswa memahami materi IPS dengan mudah.

Maka dari itu diperlukannya sebuah media pembelajaran yang kreatif, inovatif, ringkas, dan mudah dipelajari oleh siswa unuk menambah wawasan dalam memahami materi IPS secara mandiri. Berdasarkan hal yang telah dipaparkan, peneliti ingin mengembangkan suatu produk yaitu berupa media pembelajaran yang dapat digunakan oleh siswa guna membantu siswa dalam memahami konsep yang dipelajarinya. Media pembelajaran tersebut berupa media pembelajaran buku saku, media buku saku ini menggunakan strategi mind mapping untuk mempermudah pemahaman konsep siswa dalam memahami materi IPS mengenai keadaan geografis Indonesia. Materi keadaan geografis Indonesia yang luas akan mudah dipahami apabila dibentuk menjadi kedalam sebuah gagasan dalam bentuk mind mapping. Selain terdapat mind mapping, pada buku saku juga berisi penjelasan materi dari mind mapping tersebut untuk menguatkan pemahaman siswa mengenai materi tersebut.

Media buku saku berbasis mind mapping ini didesain sesuai dengan karakteristik siswa, yaitu salah satunya dengan menggunakan warna yang cerah dan berisi gambar sebagai daya tarik visual. Penggunaan mind mapping yang menonjolkan kegrafikan serta penggunaan warna yang cerah, diharapkan dapat menarik minat siswa untuk membaca serta mempelajari apa yang terdapat dalam buku tersebut. Selain itu, pengguunaan mind mapping dapat membantu siswa dalam menghubungkan sebuah konsep tunggal dengan konsep-konsep lainnya pada kategori yang sama, sehingga akan mempermudah siswa dalam mengingat maupun memahami mengenai konsep yang sedang dipelajari (Trianto, 2011:157).

Sesuai dengan namanya buku saku berbasis mind mapping merupakan buku yang berukuran kecil, dan dan praktis. Dengan buku saku berbasis mind mapping yang berukuran kecil, siswa dapat mudah membawanya kapanpun dan dimanapun. Buku saku berbasis mind mapping ini berisi materi keadaan geografis Indonesia, materi yang disajikan di dalam buku saku berbasis mind mapping ini singkat, dan jelas sehingga informasi yang siswa dapatkan akan lebih terfokus dalam mempelajari materi tersebut.

Buku saku berbasis mind mapping juga berisi soal latihan untuk mengukur sejauh mana pemahaman siswa terkait materi keadaan geografis Indonesia, serta terdapat kolom catatan. Kolom catatan dapat digunakan siswa untuk mencatat hal-hal penting yang berkaitan 
dengan materi. Dengan bantuan buku saku berbasis mind mapping, diharapkan siswa dapat belajar dimanapun dan kapanpun sehingga siswa dapat lebih memahami materi atau konsep yang dipelajarinya dengan baik dan maksimal yakni materi Keadaan Geografis Indonesia pada mata pelajaran IPS.

Berdasarkan penelitian yang dilakukan oleh Sulistyani pada tahun 2013, data yang diperoleh dari hasil rata-rata nilai belajar kelas eksperimen mencapai 81.27, sedangkan ratarata nilai belajar kelas kontrol ialah 77.73. Hasil nilai rata-rata belajar tersebut menjelaskan bahwa kelas yang menggunakan buku saku memiliki nilai hasil belajar yang lebih baik daripada dengan kelas yang tidak menggunakan buku saku. Perbedaan tersebut dikarenakan kegiatan belajar pada kelas eksperimen menggunakan media pembelajaran berupa buku saku, sedangkan pada eksperimen tidak menggunakan media buku saku.

Penelitian lainnya yang menguatkan ialah penelitian yang dilakukan Mehakati pada tahun 2017, berdasarkan hasil data yang didapat terlihat bahwa KKM pra siklus ada 15 (45\%) siswa, pada siklus I ada 17 (51\%) siswa dan pada siklus II ada 26 (79\%) siswa. Hasil pengamatan tersebut menunjukkan adanya perubahan dari siklus I sampai siklus II yakni dengan meningkatnya siswa yang aktif dan meningkatnya perhatian siswa dalam kegiatan pembelajaran. Hasil tersebut menunjukkan bahwa penggunaan mind mapping dapat membantu pemahaman siswa dalam pembelajaran terutama pada mata pelajaran IPS sehingga dapat meningkatkan hasil belajar siswa.

Berdasarkan latar belakang yang telah dipaparkan, maka peneliti akan mengembangkan suatu produk melalui penelitian pengembangan. Penelitian pengembang ini menghasilkan suatu produk yang berupa buku saku berbasis mind mapping materi keadaan geografis Indonesia.

\section{METODE PENELITIAN}

Penelitian ini menggunakan metode penelitian dan pengembangan atau Research and Development (R\&D). Metode $\mathrm{R} \& \mathrm{D}$ merupakan metode penelitian yang dipakai untuk membuat dan menghasilkan sebuah produk tertentu yang nantinya produk tersebut akan diuji keberhasilannya. Menurut Sugiyono (2010:407) metode penelitian dan pengembangan merupakan penelitian yang bersifat longitudinal (penelitian yang bertahap dengan memakan waktu yang lama). Penelitian dan pengembangan menghasilkan sebuah produk tertentu yang berdasarkan pada analisis kebutuhan. Selain itu, produk tertentu yang dihasilkan akan diuji kefektifannya sehingga dapat berfungsi untuk masyarakat luas.

Setiap pengembangan dapat memilih dan menemukan langkah-langkah yang paling tepat bagi dirinya berdasarkan kondisi khusus yang dihadapinya dalam proses pengembangan. Dengan demikian, peneliti memutuskan untuk menggunakan enam langkah dari sepuluh langkah tersebut atas dasar keterbatasan peneliti, waktu, dana, dan subjek uji coba, sehingga penelitian ini hanya sampai pada tahap uji coba terbatas. Sugiyono (2012:409) diantaranta, 1) analisis masalah, 2) pengumpulan data, 3) desain produk, 4) validasi produk, 5) revisi desain, dan 6) uji coba produk/uji coba terbatas pada siswa kelas V SDN Cimuncang Cilik yang berjumlah 17 siswa. Prosedur pengumpulan data teknik tes, wawancara tidak terstruktur, angket atau kuesioner, dan dokumentasi. Analisis data pada penelitian ini yaitu analisis kelayakan uji ahli dan analisis tes pemahaman untuk mengetahui pehaman siswa pada materi keladaan geografis Indonesia.

Analisis kelayakan uji ahli yang dilakukan bertujuan untuk mengetahui tingkat kelayakan dari produk yang sedanag dikembangkan. Analisis kelayakan uji ahli pada penelitian ini menggunakan skala likert. Penilaian yang telah diperoleh dari hasil uji ahli kemudian diolah menggunakan teknik pengolahan data sebagai berikut: 
$\mathbf{N P}=\frac{R}{S M} X 100 \%$

(Purwanto, 2013:102)

$\mathrm{NP}$ adalah nilai rata-rata persentase (\%), $\mathrm{R}$ adalah skor mentah yang diperoleh, dan
SM adalah nilai skor maksimum pada seluruh aspek. Nilai yang diperoleh kemudian diinterpretasikan sesuai dengan kriteria di bawah ini :

Tabel 1. Kriteria Interpretasi Kelayakan

\begin{tabular}{cc}
\hline $\begin{array}{c}\text { Persentase } \\
\text { Pencapaian }\end{array}$ & Interpretasi \\
\hline $0-20 \%$ & Tidak layak \\
$21-40 \%$ & Kurang layak \\
$41-60 \%$ & Cukup layak \\
$61-80 \%$ & Layak \\
$81-100 \%$ & Sangat layak \\
\hline
\end{tabular}

(Riduwan, 2009:41)

Pemahaman siswa terhadap materi keadaan geografis Indonesia diuji dengan memberikan tes pemahaman kepada siswa. Indikator pembelajaran digunakan sebagain landasan pada tes pemahaman. Setiap soal terdiri dari satu jawaban dengan skor maksimal 4. Hasil tes yang didapatkan dapat dihitung menggunakan rumus, sebagai berikut:

$$
\mathbf{N P}=\frac{\mathrm{X}_{\text {maks }}}{\text { SMI }} \times 100
$$

(Sugiyono, 2014:93)

NP adalah jumlah skor akhir/nilai akhir, Xmaks adalah skor maksimum yang didapat, dan SMI skor maksimum ideal pada seluruh indikator. Nilai yang sudah diperoleh, selanjutkan diinterpretasikan sesuai dengan kriteria di bawah ini:

Tabel 2. Kriteria Interpretasi Tes Pemahaman

\begin{tabular}{cc} 
Nilai & Kategori \\
\hline $90<\mathrm{NP} \leq 100$ & Sangat Baik \\
$80<\mathrm{NP} \leq 89$ & Baik \\
$70<\mathrm{NP} \leq 79$ & Cukup \\
$\mathrm{NP}<70$ & Kurang \\
\hline \multicolumn{2}{c}{ (Rafianti, 2013:45) }
\end{tabular}

\section{HASIL DAN PEMBAHASAN}

Penelitian dan pengembangan ini bertujuan untuk menghasilkan media pembelajaran buku saku berbasis mind mapping terharap pemahaman konsep materi keadaan geografis Indonesia di kelas V semester 1. Hasil penelitian pengembangan buku saku ini dilakukan berdasarkan prosedur pengembangan yang dikembangkan oleh Sugiyono (2015:409). Tahapan dalam penelitian pengembangan media pembelajaran buku saku berbasis mind mapping meliputi 6 tahap, yaitu analis masalah, mengumpulkan informasi data, desain produk, validasi desain/uji ahli, perbaikan desain/revisi produk dan uji coba terbatas.

Langkah awal dalam penelitian ini yaitu analisis masalah untuk menetapkan permasalahan yang terdapat di sekolah. Langkah kedua yaitu pengumpuan data dengan studi literatur dan studi lapangan. Studi literatur dilakukan dengan analisis kebutuhan, 
analisis kurikulum, dan analisis materi. Sedangkan studi lapangan dilakukan dengan melakukan wawancara, angket atau kuesioner, dan dokumentasi. Setelah pengumpulan data, langkah selanjutnya ialah desain buku saku, tahap awal pada pembuatan desain buku saku yaitu dengan membuat stody board sebagai rancangan atau gambaran awal dalam menyusun pengembangan buku saku.

Desain produk buku saku berbasis mind mapping dilakukan dengan beberapa tahap antara lain tahap pengumpulan data, pemilihan huruf, pemilihan kertas, pemilihan warna, tahap pembuatan media pembelajaran buku saku berbasis mind mapping, dan tahap penjilidan. Buku saku berukuran A6, menggunakan jenis kertas artpaper, jenis font yang digunakan yaitu Comic Sans MS, Comic Relief, dan $20 \mathrm{db}$. Tahap Pembuatan Media Buku Saku Berbasis Mind Mapping 1) membuat rancangan awal media yang akan dibuat, 2) membuat mind mapping dengan menggunakan aplikasi Imindmap, 3) membuat sampul depan dan belakang buku saku berbasis mind mapping dengan menggunakan aplikasi canva, 3) menggabungkan gambar mind mapping yang telah dibuat dengan materi menggunakan microsoft powerpoint, 4) buku saku dicetak dengan menggunakan kertas jenis Artpaper 100 gsm berukuran A6 (10,5 cm x $12,4 \mathrm{~cm})$. Berikut ini gambaran isi dari buku saku berbasis mind mapping:

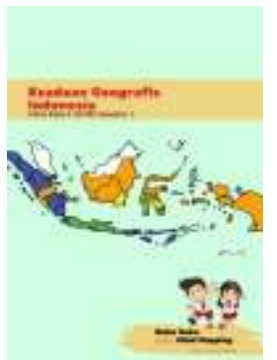

Cover Depan

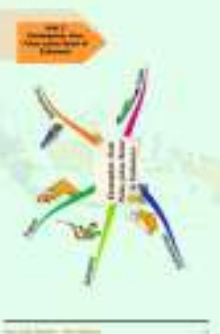

Mind Mapping

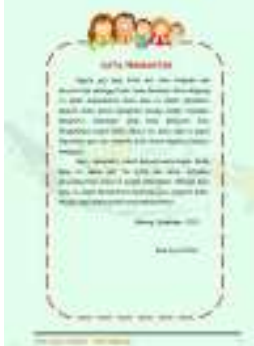

Kata Pengantar

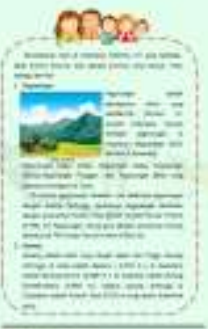

Materi

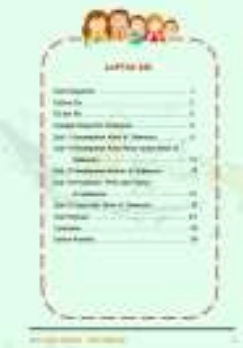

Daftar Isi

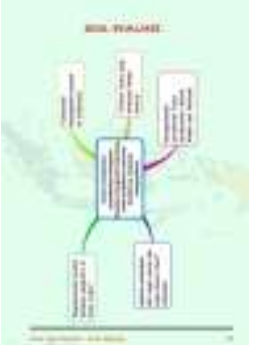

Tes Pemahaman

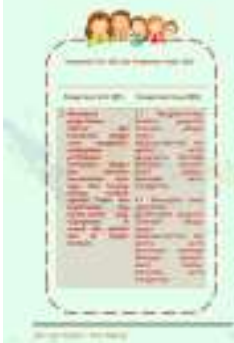

KI dan KD

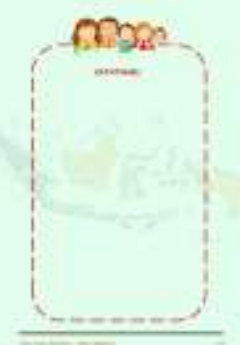

Kolom Catatan Daftar Pustaka

\section{Gambar 1. Gambar Isi Buku Saku Berbasis Mind Mapping}

Setelah pembuatan buku saku, produk yang dikembangkan akan divalidasi oleh tim ahli. Media buku saku berbasis mind mapping ini divalidasi oleh 6 orang ahli validasi, yang terdiri dari 2 dosen ahli validasi media, 2 dosen ahli validasi materi, dan 2 dosen ahli validasi bahasa. Berikut rata-rata skor validasi yang diperoleh dari tim ahli: 
ISSN : 2303-1514 | E-ISSN : 2598-5949

DOI : http://dx.doi.org/10.33578/jpfkip.v10i1.8068

https://primary.ejournal.unri.ac.id/index.php/JPFKIP

Tabel 3. Hasil Validasi Ahli Media

\begin{tabular}{|c|c|c|c|}
\hline \multirow[b]{2}{*}{ No. } & \multirow[b]{2}{*}{ Aspek Penilaian } & \multicolumn{2}{|c|}{ Skor diperoleh } \\
\hline & & Ahli I & Ahli II \\
\hline 1. & Ukuran fisik buku & 7 & 7 \\
\hline 2. & Tata letak sampul buku & 11 & 11 \\
\hline 3. & Huruf yang digunakan menarik dan mudah dibaca & 8 & 6 \\
\hline 4. & Ilustrasi sampul buku & 8 & 6 \\
\hline 5. & Konsistensi tata letak & 7 & 8 \\
\hline 6. & Unsur tata letak harmonis & 8 & 6 \\
\hline 7. & Unsur tata letak lengkap & 7 & 6 \\
\hline 8. & Tata letak mempercepat pemahaman & 7 & 8 \\
\hline 9. & Tipografi isi buku sederhana & 12 & 11 \\
\hline 10. & Tipografi mudah dibaca & 8 & 7 \\
\hline 11. & Tipografi buku memudahkan pemahaman & 4 & 4 \\
\hline 12. & Ilustrasi isi & 11 & 9 \\
\hline & Jumlah & 89 & \\
\hline & NP & $85.6 \%$ & $94.2 \%$ \\
\hline & Keterangan & San & \\
\hline
\end{tabular}

Sumber: data peneliti yang diolah

Tabel 4. Hasil Validasi Ahli Media

\begin{tabular}{clcc}
\hline \multirow{2}{*}{ No. } & \multicolumn{2}{c}{ Aspek Penilaian } & \multicolumn{2}{c}{ Skor diperoleh } \\
\cline { 3 - 4 } & & Ahli I & Ahli II \\
\hline 1. & Kesesuaian materi dengan KD & 10 & 11 \\
2. & Keakuratan materi & 14 & 15 \\
3. & Pendukung materi pembelajaran & 16 & 14 \\
4. & Kemutakhiran materi & 11 & 11 \\
& Jumlah & 51 & 51 \\
& NP & $91 \%$ & $91 \%$ \\
& Keterangan & \multicolumn{2}{c}{ Sangat Layak } \\
\hline
\end{tabular}

Sumber: data peneliti yang diolah

Tabel 5. Hasil Validasi Ahli Bahasa

\begin{tabular}{|c|c|c|c|}
\hline \multirow{2}{*}{ No. } & \multirow{2}{*}{ Aspek Penilaian } & \multicolumn{2}{|c|}{ Skor diperoleh } \\
\hline & & Ahli I & Ahli II \\
\hline 1. & Lugas & 9 & 10 \\
\hline 2. & Komunikatif & 4 & 4 \\
\hline 3. & Dialogis dan interaktif & 8 & 8 \\
\hline 4. & Kesesuaian dengan perkembangan peserta didik & 8 & 8 \\
\hline 5. & Kesesuaian dengan kaidah bahasa & 3 & 3 \\
\hline \multirow[t]{4}{*}{6.} & Penggunaan istilah, simbol atau ikon & 9 & 6 \\
\hline & Jumlah & 39 & 41 \\
\hline & NP & $81.3 \%$ & $84.4 \%$ \\
\hline & Keterangan & \multicolumn{2}{|c|}{ Sangat Layak } \\
\hline
\end{tabular}

Sumber: data peneliti yang diolah

Setelah Buku Saku Berbasis Mind Mapping melewati kelima tahap yang yang

telah dilakukan, tahap selanjutnya pada penelitian ini ialah uji coba terbatas yang 
dilakukan pada tanggal 13 Oktober 2020 di kelas V SDN Cimuncang Cilik dengan sampel penelitian sebanyak 17 orang siswa. Uji coba terbatas dilakukan bertujuan untuk mengetahui pemahaman siswa terhadap materi Keadaan Geografis Indonesia. Tes pemahaman yang digunakan adalah soal uraian yang berjumlah 5 soal, yang diberikan pada akhir kegiatan pembelajaran. Berikut adalah hasil tes pemahaman siswa kelas V SDN Cimuncang Cilik terhadap materi Keadaan Geografis Indonesia.

Tabel 6. Hasil Tes Pemahaman Siswa

\begin{tabular}{ccccccc}
\hline Hasil Tes & \multicolumn{5}{c}{ Nomor Soal } & Nilai \\
\cline { 2 - 7 } Pemahaman & $\mathbf{1}$ & $\mathbf{2}$ & $\mathbf{3}$ & $\mathbf{4}$ & $\mathbf{5}$ & Akhir \\
\hline Nilai & 100 & 95.6 & 88.2 & 86.8 & 70.6 & 88.2 \\
\hline Ketarangan & $\begin{array}{c}\text { Sangat } \\
\text { Baik }\end{array}$ & $\begin{array}{c}\text { Sangat } \\
\text { Baik }\end{array}$ & Baik & Baik & Cukup & Baik \\
\hline
\end{tabular}

Sumber: data peneliti yang diolah

\section{Pembahasan}

Pengembangan media pembelajaran Buku Saku berbasis Mind Mapping ini digunakan untuk membantu guru dan siswa dalam kegiatan pembelajaran. Media pembelajaran Buku Saku berbasis Mind Mapping diharapkan dapat menunjang kegiatan pembelajaran menjadi pembelajaran yang efektif dan efisien sehingga kompetensi serta tujuan pembelajaran dapat tercapai dan mendapatkan pengetehuan, sikap, maupun keterampilan. Hal itu sependapat dengan Heinich (Pribadi, 2017:15) bahwa media pembelajaran merupakan media yang digunakan untuk mendukung aktivitas pembelajaran guna memperoleh ilmu pengetahuan, keterampilan, dan sikap.

Pada Buku Saku berbasis Mind Mapping terdapat materi mengenai Keadaan Geografis Indonesia yang merujuk pada KD 3.1 dan 4.1 Tema 1 Sub Tema 2 sehingga Buku Saku berbasis Mind Mapping ini dapat dijadikan sebagai buku pelengkap atau buku referensi yang dapat digunakan siswa selama proses pembelajaran. Hal itu sesuai dengan Prastowo (Su'udiah, dkk, 2016:1744) buku teks berisi ilmu pengetahuan yang dikembangkan menurut kompetensi dasar dalam kurikulum, yang digunakan oleh siswa untuk belajar.

Media pembelajaran buku saku ini menggunakan teknik pemetaan pikiran atau mind mapping. Penggunaan teknik mind mapping dimaksudkan untuk mempermudah siswa dalam memahami materi yang dipelajari khususnya materi keadaan geografis Indonesia. Karena mind map menonjolkan unsur kegrafikan yakni penggunaan warna serta simbol yang dapat mempermudah siswa dalam memahami dan mengingat materi yang dipelajarinya. Hal tersebut sesuai dengan pendapat Shoimin (2014:105) bahwa mind mapping merupakan teknik yang memanfaatkan seluruh bagian otak dengan menggunakan visual dan grafis untuk membentuk sebuah kesan sehingga otak dapat merekam informasi-informasi dalam bentuk gambar, simbol, suara, maupun bentuk lainnya.

Buku Saku berbasis Mind Mapping dibentuk menjadi buku saku yang menarik dengan memperhatikan pemilihan dan penggunaan warna, gambar, ilustrasi gambar, dan desain sesuai dengan kebutuhan serta perkembangan peserta didik. Selain itu, isi pada Buku Saku berbasis Mind Mapping dibuat ringkas dan jelas agar siswa mudah menyerap materi. Menurut Sulistyani (Asyahari, 2016:5) dalam menyusun buku saku ada beberapa hal yang harus diperhatikan, antara lain 1) penggunaan simbol dan istilah pada buku saku harus konsisten; 2) penulisan materi pada buku saku secara singkat dan jelas; 3) enyusunan teks materi dibuat sedemikian rupa sehingga dapat mudah dipahami; 4) memberikan kotak atau tanda khusus pada 
bagian rumus, pemusatan pada materi dan contoh soal yang terdapat pada buku saku; dan 5) menyajikan warna serta desain yang menarik pada buku saku.

Keberhasilan Buku Saku berbasis Mind Mapping dapat dilihat berdasarkan hasil validasi uji ahli media, ahli materi, dan ahli bahasa, serta pemahaman siswa selama proses pembelajaran setelah menggunakan Buku Saku berbasis Mind Mapping. Hasil validasi uji ahli media yang telah dilakukan memperoleh persentase skor dari validator ahli I yakni $85.6 \%$ dan hasil validasi uji ahli media oleh validator II memperoleh persentase skor $94 \%$. Berdasarkan hasil yang diperoleh dari validasi yang dilakukan oleh kedua validator ahli memperoleh rata-rata ketercapaian persetase skor sebesar $89.2 \%$. Nilai tersebut masuk pada kriteria kategori interpretasi "Sangat Layak" (Riduwan, 2009:41) sehingga layak digunakan di lapangan. Meskipun layak digunakan, terdapat beberapa perbaikan yang disarankan oleh kedua validator ahli, yaitu mengganti ukuran huruf yang digunakan menjadi lebih besar dari sebelumnya, margin atau batas kertas dibuat menjadi lebih tipis, menambahkan lembar evaluasi untuk membuat mind mapping, dan menambahkan gambar animasi yang sesuai dengan materi.

Uji validasi ahli materi yang telah dilakukan oleh kedua validator ahli materi memperoleh persentase skor dari validator ahli materi I yakni $91 \%$ dan hasil validasi uji ahli oleh validator materi II memperoleh persentase skor $91 \%$. Berdasarkan hasil dari kedua ahli materi, memperoleh rata-rata ketercapaian persetase skor sebesar $91 \%$ dengan kriteria katergori interpretasi "Sangat Layak" untuk digunakan di lapangan (Riduwan, 2009:41). Dari penilaian yang telah dilakukan, terdapat beberapa perbaikan yang disarankan oleh kedua ahli materi, yaitu penulisan pada soal evaluasi yang semula "Sebutkan" menjadi "Tuliskan" dan menambahkan keterangan pada gambar mind mapping setiap sub materi, seperti "Mind Mapping Kenampakan Alam di Indonesia".

Uji validasi ahli bahasa yang telah dilakukan memperoleh skor persentase dari validator ahli bahasa I sebesar $81.3 \%$ dan dari validator ahli bahasa II memperoleh hasil sebesar 84,4\%. Berdasarkan skor yang diperoleh dari kedua ahli, memperoleh nilai rata-rata ketercapaian persentase skor sebesar $82.8 \%$ dengan kriteria interpretasi "Sangat Layak" sehingga layak digunakan di lapangan (Riduwan, 2009:41). Meskipun demikian, terdapat perbaikan yang disarankan oleh kedua ahli bahasa, yaitu memperbaiki struktur kalimat, penggunaan huruf kapital seperti "jazirah arab" menjadi "Jazirah Arab", dan penggunaan tanda baca. Berikut adalah hasil rata-rata skor yang diperoleh dari masingmasing ahli, yakni ahli media, ahli materi, dan ahli bahasa.

Tabel 7. Rata-rata Skor Validasi Ahli

\begin{tabular}{ccc}
\hline Validasi & Persentase $(\boldsymbol{\%})$ & Kategori \\
\hline Ahli Media & 89.2 & Sangat Layak \\
Ahli Materi & 91 & Sangat Layak \\
Ahli Bahasa & 82.8 & Sangat Layak \\
Rata-rata Skor & $\mathbf{8 7 . 7}$ & Sangat Layak \\
\hline
\end{tabular}

Dilihat dari hasil rata-rata persentase skor masing-masing para ahli (media, materi, dan bahasa), secara keseluruhan uji kelayakan yang telah dilakukan memperoleh hasil nilai persentase sebesar 87.7\%. Menurut Riduwan (2009:41) hasil nilai rata-rata uji kelayakan yang diperoleh masuk ke dalam kriteria interpretasi kelayakan dengan kategori "Sangat Layak", sehingga media pembelajaran Buku Saku Berbasis Mind Mapping ini layak untuk diujicobakan. Buku Saku Berbasis Mind Mapping yang telah diperbaiki berdasarkan 
saran serta masukan dari tim ahli, kemudian diujicobakan di kelas V SDN Cimuncang Cilik dengan jumlah 17 orang siswa pada tanggal 13 Oktober 2020. Tempat pelaksanaan uji coba terbatas bertempat di rumah Bapak Nanang selaku wali kelas VB SDN Cimuncang Cilik, alasan peneliti melakukan uji coba terbatas di luar sekolah dikarenakan selama pandemi COVID-19 sekolah tidak melakukan kegitatan belajar mengajar di kelas. Tes pemahaman diberikan pada akhir pembekalajaran dengan memberikan soal tes pemahaman berjumlah 5 butir soal uraian kepada siswa. Hasil perhitungan setiap soal mendapatkan hasil yang berbeda-beda. Pada butir soal pertama memperoleh nilai rata-rata sebesar 100 dengan kategori "Sangat Baik" nilai tersebut adalah nilai rata-rata tertinggi, pada butir soal kedua memperoleh hasil nilai rata-rata sebesar 95.6 dengan kategori "Sangat Baik", butir soal ketiga memperoleh hasil nilai rata-rata sebesar 88.2 dengan kategori "Baik", butir soal keempat memperoleh hasil nilai rata-rata sebesar 86.8 dengan kategori "Baik", dan butir soal memperoleh hasil nilai terendah dengan rata-rata sebesar 70.6 dengan kategori "Cukup". Hasil perhitungan 5 butir soal tes pemahaman siswa diperoleh rata-rata nilai akhir sebesar 88.2, rata-rata nilai akhir tes pemahaman tersebut menunjukkan hasil dengan kategori "Baik" (Rafianti, 2013:45). Berdasarkan hasil rata-rata nilai akhir yang diperoleh, dapat dikatakan bahwa penggunaan Buku Saku Berbasis Mind Mapping dapat meningkatkan pemahaman konsep siswa terhadap materi keadaan geografis Indonesia.

Berdasarkan hasil data yang diperoleh hasil penelitian ini relevan dengan penelitian yang dilakukan oleh Sumantri dan Firmansyah (2016) memperoleh hasil dari uji coba lapangan dengan nilai rata-rata persentase $86 \%$ dengan kategori sangat baik dan nilai efektifitas buku saku pada tahap uji coba lapangan memperoleh nilai rata-rata 83. Selain itu, hasil penelitian ini relevan dengan penelitian yang dilakukan oleh Rahmasari (2018) memperoleh hasil penilaian oleh ahli materi dengan nilai rata-rata persentase $68 \%$ dan ahli materi memperoleh nilai rata-rata persentase $72 \%$ dengan kategori Layak yang berarti efektifitas buku saku layak untuk digunakan.

\section{SIMPULAN DAN REKOMENDASI}

Berdasarkan dari perumusan masalahan yang telah dirumuskan pada Pengembangan Media Pembelajaran Buku Saku Berbasis Mind Mapping terhadap Pemahaman Konsep Materi Keadaan Geografis Indonesia di Kelas V SD, dapat disimpulkan sebagai berikut: 1) pengembangan media pembelajaran buku saku berbasis mind mapping terhadap pemahaman konsep materi keadaan geografis Indonesia di Kelas V SD, dilaksanakan berdasarkan langkah-langkah penelitian dan pengembangan menurut Borg and Gall dimodifikasi oleh Sugiyono, yakni tahap analisis masalah, pengumpulan data, desain buku saku berbasis mind mapping, validasi buku saku berbasis mind mapping, revisi desain buku saku berbasis mind mapping, dan uji coba buku saku berbasis mind mapping/uji coba terbatas. 2) media pembelajaran buku saku berbasis mind mapping materi keadaan geografis Indonesia dapat dikatakan sangat Layak berdasarkan uji validasi oleh ahli media memperoleh hasil $89.2 \%$ dalam kategori "sangat layak", ahli materi memperoleh hasil $91 \%$ dalam kategori "sangat layak", dan ahli bahasa memperoleh hasil $82.8 \%$ dalam kategori "sangat layak", dan 3) pemahaman siswa terharap materi keadaan geografis Indonesia setelah menggunaakan media pembelajaran buku saku berbasis mind mapping memperoleh hasil baik yang dapat dilihat berdasarkan hasil tes pemahaman siswa dengan nilai rata-rata 88.2 termasuk dalam kategori "Baik".

\section{Rekomendasi}

Berdasarkan simpulan diatas, peneliti memberikan beberapa rekomendasi, yaitu pengembangan media pembelajaran buku saku berbasis mind mapping materi keadaan 
geografis Indonesia dapat dikembangkan kembali dengan materi yang berbeda dan media pembelajaran buku saku berbasis mind mapping materi keadaan geografis Indonesia yang dikembangkan dapat digunakan sebagai sumber belajar siswa secara mandiri, baik di sekolah maupun di luar sekolah.

\section{DAFTAR PUSTAKA}

Arikunto, S. (2006). Prosedur Penelitian Suatu Pendekatan Praktik. Jakarta: Bineka Cipta.

Arsyad, A. (2011). Media Pembelajaran. Jakarta: PT Raja Grafindo.

Asyari, A. dan Helda. S. (2016). Pengembangan Media Pembelajaran Berupa Buletin dalam Bentuk Buku Saku untuk Pembelajaran IPA Terpadu. Jurnal Ilmiah Pendidikan Fisika, 5(1), 1-13.

Buzan, T. (2007). Buku Pintar Mind Map. Jakarta: Gramedia Pustaka Utama.

Eliana, D. dan Solikhah. (2012). Pengaruh Buku Saku Gizi terhadap Tingkat Pengetahuan pada Anak Kelas 5 Muhammadiyah Dadapan Desa Wonokerto Kecamatan Turi Kabupaten Sleman Yogyakarta. Jurnal KESMAS, 6(2), 162-232.

Hartati, S. dkk. (2017). Pengaruh Kemampuan Pemahaman Konsep, Kemampuan Komunikasi dan Koneksi Terhadap Kemampuan Pemecahan Masalah. Jurnal Pendidikan Matematika, 11(2), 41-59.

Komariah, S. dkk. (2018). Analisis Pemahaman Konsep dalam Memecahkan Matematika ditinjau dari Minat Belajar Siswa: Sosiohumaniora. Jurnal LP3M Universitas Sarjanawiyata Tamansiswa Yogyakart, 4(2), 2-3.

Mehakati, F. U. (2017). Peningkatan Hasil Belajar Siswa Menggunakan (Mind Mapping) pada Mata Pelajaran IPS Kelas V SD. Jurnal Pendidikan Guru Sekolah Dasar, 7(6), 678-684.
Purwanto, M. N. (2013). Prinsip-prinsip dan Teknik Evaluasi Pembelajaran. Bandung: PT Remaja Rosdakarya.

Purwono, U. (2008). Standar Penilaian Buku Pelajaran. Jakarta: Badan Standar Nasional Pendidikan.

Rafianti, I. (2013). Penerapan Model Pembelajaran Matematika Berbasis Multiple Intelligences untuk Meningkatkan Kemampuan Pemahaman Konsep, Pelajaran Matematis dan Self-Confidence Peserta Didik MTS. Skripsi. Bandung: Universitas Pendidikan Indonesia.

Riduwan. (2009). Belajar Mudah Penelitian untuk Guru Karyawan dan Peneliti Pemula. Bandung: Alfabeta.

Shoimin, A. (2014). 68 Model Pembelajaran Inovatif dalam Kurikulum 2013. Yogyakarta: Ar-Ruzz Media.

Sugiyomo. (2014). Metode Penelitian Pendidikan Pendekatan Kuantitatif, Kualitatif, dan R\&D. Bandung: Alfabeta.

Sugiyono. (2010). Metode Penelitian Pendidikan Pendekatan Kuantitatif, Kualitatif, dan $R \& D$. Bandung: Alfabeta.

Sugiyono. (2012). Metode Penelitian Pendidikan Pendekatan Kuantitatif, Kualitatif, dan R\&D. Bandung: Alfabeta.

Sugiyono. (2015). Metode Penelitian Pendidikan Pendekatan Kuantitatif, Kualitatif, dan $R \& D$. Bandung: Alfabeta.

Sugiyono. (2016). Metode Penelitian Pendidikan Pendekatan Kuantitatif, Kualitatif, dan $R \& D$. Bandung: Alfabeta.

Sukmadinata, N. S. (2013.) Metode Penelitian Pendidikan. Bandung: PT Remaja Rosdakarya.

Sulistyani, N. H. D. (2013). Perbedaan Hasil Belajar Siswa antara Menggunakan Media Pocket Book dan Tanpa Pocket Book pada Materi Kinematika Gerak 


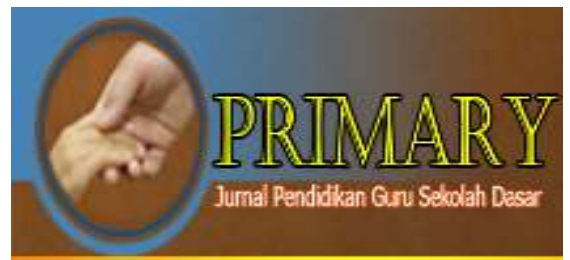

PRIMARY: JURNAL PENDIDIKAN GURU SEKOLAH DASAR

VOLUME 10 NOMOR 1 FEBRUARI 2021

ISSN : 2303-1514 | E-ISSN : 2598-5949

DOI : http://dx.doi.org/10.33578/jpfkip.v10i1.8068

https://primary.ejournal.unri.ac.id/index.php/JPFKIP

Melingkar Kelas X. Jurnal Pendidikan Fisik, 1(1), 171.

Yuliani, F. dan Lina H. (2015). Pengembangan Buku Saku Materi Pemanasan Global untuk SMP. Jurnal Pendidikan Biologi, 4(1), 104-110. 